\title{
SINTAKSA AKTIVNIH PARTICIPA U HRVATSKOGLAGOLJSKOM PSALTIRU
}

U radu se na korpusu hrvatskoglagoljskih psaltira (Lobkovicova, Pariškoga i Fraščićeva) raščlanjuju aktivne participske konstrukcije u uporabama: pridjevskim (pravi pridjevski i poimeničeni participi) i glagolskim (priložni, perifrastični, samostalnoga predikata, dopunski), na temelju usporedbe s grčkim originalom kao i čitanjima kanonskoga Sinajskoga psaltira. Zanimljiva pojava variranja određenih i neodređenih oblika, osobito u prijenosu grčkih beščlanskih participa ukazuje na težu gramatičku identifikaciju koju mogu uvjetovati: zajednička obilježja samih participskih vrsta, bezvremenost kao obilježje književnoga žanra, razlike između dvaju jezika i neizravan utjecaj hebrejske sintakse. U razmatranju se uzima u obzir razumijevanje prevoditeljske tehnike, povremena odstupanja u određenosti sklonidbenih oblika u odnosu na grčki predložak, varijacije među crkvenoslavenskim rukopisima kao i utjecaj latinske Vulgate.

Ključne riječi: particip, sintaksa, hrvatskoglagoljski psaltir, hrvatski crkvenoslavenski jezik, grčki jezik

\section{UVOD}

Hrvatskoglagoljski prijepisi psaltira, iako iz 14. i 15. stoljeća, tekstološki pripadaju prvoj, arhaičnoj redakciji psaltirskoga teksta čiji su najstariji sačuvani spomenici iz 11. stoljeća. Važnost ove starozavjetne knjige u svakodnevnom životu Crkve kao i tekstološka i jezična obilježja pokazuju veliku starinu prijevodnoga teksta iz razdoblja moravske misije u drugoj polovici 9. stoljeća, dok je od kasnijih promjena u pojedinostima vidljivo naknadno prilagođavanje latinskoj Vulgati (Usp. MACROBERT 1998: 921).

M. Valjavec je u radu o prijevodu psalama u nekim crkvenoslavenskim psaltirima primijetio da particip u tekstu glagoljskoga psaltira dolazi većinom 
na onim mjestima gdje ga ima i u grčkom originalu, dok je u latinskom tekstu odnosna rečenica (usp. VALJAVEC 1889: 31-33). F. Pastrnek je u radu o prijevodu grčkih članskih konstrukcija u starocrkvenoslavenskom prijevodu psaltira i evanđelistara usporedio i dopunio Valjavčeve primjere (usp. PASTRNEK 1903: 366-391). ${ }^{1}$ U studiji o članu u slavenskim jezicima J. Kurz se bavi pitanjem prijevoda grčkoga participa s članom u starocrkvenoslavenskom korpusu evanđelja i psaltira (usp. KURZ 1937-1938; 1939-1946). Psaltirske primjere preuzima iz Pastrnekove studije, provjerene prema novijem Sever'janovljevu izdanju Sinajskoga psaltira. Sintaksom aktivnih participa u starocrkvenoslavenskom jeziku i njihovim odnosom prema grčkom originalu bavi se R. Večerka prilažući, uz primjere iz kanonskih tekstova evanđelja, molitava i žitija, i one iz kanonskoga Sinajskoga psaltira (VEČERKA 1961). Na korpusu hrvatskih crkvenoslavenskih misala temeljena je sintaktička studija J. Reinharta, koja zahvaća i participske konstrukcije. Supostavljajući varijante iz usporednih istočnih tekstova kao i grčke i latinske paralele autor prati u kojoj je mjeri tekst u pojedinim hrvatskoglagoljskim tekstovima arhaičan ili pomlađen (REINHART 1993).

U ovom će se radu opisati oblici, uporabe i rečenične uloge aktivnoga participa prezenta i prvoga aktivnoga participa preterita u hrvatskoglagoljskom psaltiru. Oni, za razliku od od $l$ - i trpnih participa, u sintaktičke odnose u rečenici ulaze kao samostalne jedinice. Morfološki su pravi pridjevi, s punom imeničkom i pridjevskom sklonidbom, te se mogu slagati ne samo sa subjektom nego i s rečeničnim članovima u kosim padežima (VEČERKA 1961: 5; HCJ 2014: 184). Razmotrit ćemo kakav je njihov odnos prema participima i konstrukcijama grčkoga predloška.

Prije usporedbe u sljedećem će se poglavlju predstaviti kratak pregled povijesnoga razvoja i poimanja participa u grčkom jeziku kao i utjecaj hebrejskoga jezika i književnosti na prijevod i uporabu participa u grčkom Starom zavjetu.

\section{PARTICIPI U GRČKOM JEZIKU}

O dvostrukoj naravi participa, pridjevskoj i glagolskoj, govori već njegovo

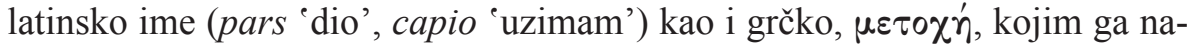

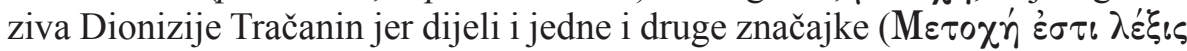

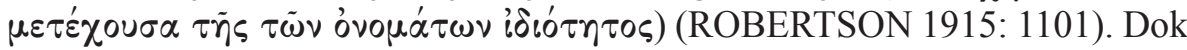
pridjev izražava kvalitetu u mirovanju, particip je predstavlja u kretanju. Po-

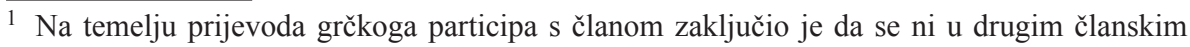
konstrukcijama ne može računati s utjecajem latinskoga prijevoda. 
put glagola može upravljati objektima i imati druge dopune svojstvene glagolima. Već kod Homera i Hezioda particip je potpuno razvijena vrsta riječi. Kod potonjega je uglavnom atributan, dok je u predikatnom položaju manje uobičajen nego kod Homera. U grčkom se posebno razvila uporaba participa kao književnoga sredstva u značenju priložne surečenice, osobito kod povjesničara i govornika (ROBERTSON 1915: 1098; 1110). Vođenjem misli, tj. tvrdnje prema finitnom glagolu, participi iziskuju manje energije u procesu razumijevanja čineći komunikaciju protočnijom, što omogućuje slušateljima da lakše slijede osnovne crte govora (RUNGE 2016, chapter 7).

U usporedbi s infinitivom, u čijoj je biti da se njime iskazana radnja osjeti kao naumljena ili moguća, particip iskazuje stvarnost i objektivnost, tj. postojanje neke radnje (DUKAT 2003: 331). Osim toga, dok je infinitiv apstraktan, particip je konkretan jer govori o osobi ili stvari koja radi ili djeluje (WALLACE 1996: 620).

\subsection{Prijevodni jezik}

Dok u morfologiji i leksiku Septuaginta pristaje u suvremenu grčku koine, sintaksa uvelike pokazuje da je riječ o prijevodnom jeziku (SOISALON-SOININEN 1973: 1). U Novom zavjetu particip se upotrebljava češće nego u Starom, gdje je na nj donekle ograničujući utjecaj imao biblijski hebrejski jezik, što se osobito očituje u rjeđoj uporabi participa kao priložne surečenice (ROBERTSON 1915: 1099).

Izostanak deklinacije kod hebrejskoga participa utječe na teže određivanje njegova karaktera. Hebrejski participi u ulozi odnosnih surečenica obično dolaze iza imenice na koju se odnose (WALTKE; O'CONNOR 1990: 612). Aktivni particip može u biblijskom hebrejskom imati značenja i karakteristike kakve imaju imenica (uglavnom nomen agentis) i pridjev upotrijebljen atributno i predikatno. Osim toga, hebrejski aktivni particip može imati ulogu predikata i odnosne surečenice (WALTKE; O'CONNOR 1990: 613). Na grčki se prevodi participima, indikativima (najčešće onim prezenta aktivnoga) te imenicama.

U grčkom jeziku helenističkoga razdoblja primjetna je veća pojava analitičkih glagolskih oblika, kako infinitivnih tako i participskih. Iako se grčka perifrastična konstrukcija tvorena od participa prezenta s glagolom biti u prezentu i imperfektu pojavljuje i u klasičnom razdoblju, postaje češćom i obuhvatnijom u doba koine, jače naglašavajući durativnost radnje od sintetičkih oblika i smanjujući donekle njihovu uporabu. Opisni oblici glagola biti u prezentu s participima perfekta i aorista nadomještaju sintetičke oblike perfekta i aorista (BROWNING 1983: 32). U grčkom Starom zavjetu u uporabi 
perifrastičnih oblika ulogu je mogao igrati hebrejski predložak. Dok bi u klasičnom grčkom iza beščlanske imenice bila bolja odnosna rečenica, u Bibliji iza beščlanske imenice često stoji članski particip.

\subsection{Hebrejsko pjesništvo}

Obilježja pjesničkoga žanra očituju se u prozodiji, retorici, obliku pjesme kao i uopće u jeziku psalama. Ova poezija sažetija je od proze, bogata u slikovitosti i metafori te evokativnija, obilujući aliteracijom, paronomazijom, hijazmom, inkluzijom i elipsom te brojnim slikama i metaforom (BROWN 2014: 2). Teže ju je i definirati i opisati, u svemu, pa i u jeziku (STEK 1974: 15-16). Dok u proznim povijesno-narativnim dijelovima Staroga zavjeta glagolski oblici prirodno ulaze u prošlo, sadašnje i buduće vrijeme, zakonski tekstovi kao i mudrosna književnost po prirodi su bezvremenski (SAILHAMER 1991: 17). Hebrejska se poezija poput kanaanske gradi na misli u paralelnim, uravnoteženim stihovima čija je duljina promjenjiva, ali i ograničena (BROWN 2014: 82). Svaki sljedeći segment može pojačavati, mijenjati ili dopunjavati misao prethodnoga retka. Elipsa je bila korištena čak i češće nego što se pretpostavljalo, osobito elipsa članova, čestica i pomoćnih glagola, dok je značajan udio punoznačnih riječi (STEK 1974: 21). Sintaktičke strukture nisu odviše složene; primjerice, rijetko je pretjerano uvođenje surečenica.

\section{GRAMATIČKE KATEGORIJE PARTICIPA}

Značenje zajedničko svim participskim ulogama svojevrsna je linearnost. Imperfekt umnaža radnju, a particip ju produljuje. Zanemari li se imenička uporaba, moglo bi se reći da particip kao glagolski pridjev više nastoji opisati stanje stvari nego predstaviti događaj sam po sebi (WALTKE; O'CONNOR, 613-614).

Na potvrdama iz hrvatskoglagoljskoga psaltira razmotrit ćemo gramatičke kategorije participa, pridjevskih (3.1.) i glagolskih (3.2.), uspoređujući ih s istovrsnim elementima u grčkom predlošku. ${ }^{2} \mathrm{U}$ ovom se radu u funkcionalnoj

2 Hrvatske crkvenoslavenske psaltirske potvrde uzimane su iz Fraščićeva psaltira (HAMM 1967) te iz Lobkovicova i Pariškoga psaltira (VAJS 1916). Uz hrvatske crkvenoslavenske donose se i inačice iz kanonskoga starocrkvenoslavenskoga Sinajskoga psaltira (SEVER'JANOV 1922 [21954] te ponegdje prema istom izdanju kao pomoćni izvori inačice iz Pogodinova i Bolonjskoga psaltira, kraticama Pog Bon). Grčke pak paralele preuzete su iz kritičkoga izdanja Septuaginte (RAHLFS 1931). Radi veće značenjske jasnoće dodane su i latinske paralele, prema kritičkom izdanju Vulgate (Vg 1953). U pravopisu crkvenoslavenskih primjera zanemaruju se razlike u bilježenju apostrofa. U usporedbi hrvatskoglagoljskih 
podjeli participa primjenjuju klasifikacije koje za novozavjetni grčki jezik daju BOYER (1984: 163-180), STRAUB (2010), TURNER (1963), WALLACE (1996) te za crkvenoslavenske aktivne participe VEČERKA (1961).

Kanonski starocrkvenoslavenski psaltirski primjeri i njihova tumačenja koje Večerka navodi u svojoj studiji bili su polazište za nalazak sličnih hrvatskih crkvenoslavenskih primjera. ${ }^{3}$ Posebna pozornost posvećena je strukturnim obrascima participa u grčkom jeziku i njihovu prijenosu u hrvatski crkvenoslavenski prijevod.

\subsection{Pridjevske uporabe}

Participi su u ovoj službi u psaltiru česti, na mjestu grčkoga pravoga pridjevskoga (3.1.1.) i poimeničenoga participa (3.1.2.) koji stoji samostalno kao imenica, s daljnjim potpodjelama prema tvorbenim obrascima u grčkom jeziku. Provjerit ćemo koji se od tih obrazaca pojavljuju u hrvatskoglagoljskom psaltiru. Njihove kratice navode se prema engleskom jeziku. ${ }^{4}$

Kada je riječ o participima u crkvenoslavenskom jeziku, valja navesti Miklošičevo pravilo o utjecaju redoslijeda nekoliko pridjevskih participa na njihov oblik, određeni (složeni) i neodređeni (jednostavni). Prema F. Miklošiču, a u tome se slažu još neki proučavatelji, prvi particip dolazi u određenom obliku, a svi sljedeći u neodređenom. ${ }^{5}$ Istu pravilnost za grčki jezik uočio je G. Sharp (DANA; MANTEY 1957: 147). Međutim, na temelju iščitavanja Kurza, Grünenthala, Tolstoja, Brodowske-Honowske te svojih vlastitih proučavanja Večerka primjećuje da staroslavenski prijevod u tome ne prati doslovno grčki. Opis koji slijedi pokazat će, između ostaloga, kako se to pravilo primjenjuje u hrvatskoglagoljskom psaltiru.

\subsubsection{Pravi pridjevski particip}

Ovaj particip ima službu imenskoga atributa ili, rijetko, predikata, modificirajući imenicu ili zamjenicu uz koju stoji. Često je, premda ne uvijek, prijevod aktivnih grčkih participa s članom, dok u latinskom jeziku obično dolazi

psaltira, ondje gdje nije pojedinačno istaknuto, valja uzeti u obzir da Fraščićev psaltir nije sačuvan u cijelosti, nego da nedostaju redci u: Ps 28,4-30,10; 33-34; 36,30-37; 66,5-77,4; 77,20-77,38a; 82,9-84,14a; 112,7-120,7a.

3 VEČERKA 1961.

4 A (article 'član'), N (noun 'imenica'), P (participle 'particip') prema BOYER 1984.

5 Isto misle i drugi proučavatelji, npr. Th. Forssmann, H. F. Schmid, G. Angelova i J. Łoś (prema VEČERKA 1961: 24). 
odnosna rečenica ili katkada također particip. Postpozicija sročnoga atributa u crkvenoslavenskom češća je od antepozicije (VEČERKA 1961: 41).

\subsubsection{Determinativni particip}

Riječ je o grčkom participu s članom koji definira pojedinca ili kategoriju pokazivanjem na specifičnu značajku. Dolazi u atributnom položaju uz imenicu. U latinskom se ovaj particip prevodi odnosnom rečenicom (BOYER 1984: 164).

$A P N($ član+particip+imenica): u ovoj konstrukciji particip zauzima prvi atributni položaj, tj. onaj nakon člana te ispred imenice. Takav je atribut očekivaniji kada je riječ o pridjevima. U psaltiru nisam našla primjere za ovu kategoriju.

ANAP (član+imenica+član+particip): u ovoj konstrukciji particip zauzima drugi atributni položaj, određen je članom i nalazi se iza imenice s članom. U latinskom se ovaj particip prevodi odnosnom rečenicom (BOYER 1984: 164):

(1) [d]oideže vzvêĉu mišcu tvoû rodu vsemu grêduĉumu Lob greduĉumu Par deest Fr; grjędQštûmu Sin

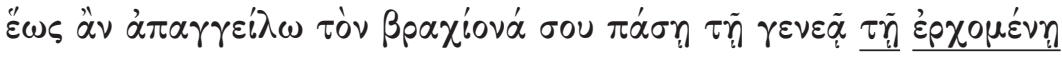
donec adnuntiem brachium tuum generationi omni quae ventura est - Ps $70,18 .^{6}$

NAP (imenica + član + particip): particip je u trećem atributnom položaju, odnosno slijedi iza opće imenice i svoga člana. Ova je konstrukcija nešto rjeđa.

(2) a. bl(agoslo)vit se č(lovê)kь boei se g(ospod)a Lob Par Fr; bojęi sję Sin

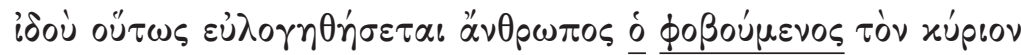
ecce sic benedicetur homo qui timet Dominum - Ps 127,4,7

b. pomoĉnikь v skrbehь obretših ni zelo Lob ob'rêt'ših' Par Fr; obrêtzšihı Sin

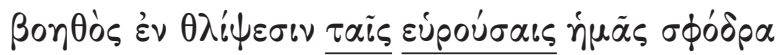

adiutor in tribulationibus quae invenerunt nos nimis - Ps 45,2.

Primjer $2 a$ mogao bi se također podvesti pod kategoriju poimeničenoga članskoga participa, $A P(3.1 .2 .1$.), u apoziciji prema imenici iza koje slijedi.

${ }^{6}$ Usp. i Ps 3,$7 ; 34,27 ; 76,15 ; 85,2 ; 112,5-8 ; 113,7-8 ; 134,1 ; 134,21$.

7 Usp. i Ps 24,12 . 
Iako bi, prema ranije navedenom Miklošičevu pravilu, u slijedu nekoliko participa samo prvi particip u hrvatskom crkvenoslavenskom i kanonskom Sinajskom psaltiru trebao dolaziti u određenom obliku, primjer 3 pokazuje da i sljedeći participi mogu biti u određenom obliku:

(3) i pravda ego na s(i)nêhь s(i)n(o)vb, hranêcihihb zavets ego; i pominaûcihb zap(o)v(ê)di ego tvoriti e Lob h'raneĉih' ... pominaûcih' Par hranecìh' ... pomeneĉih'Fr; hranjęciihı ... pomsnjęcihı Sin

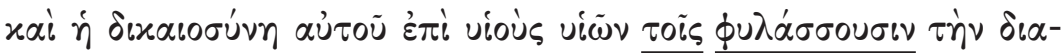

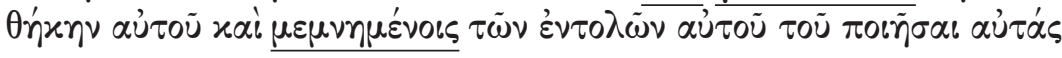
et iustitia illius in filios filiorum his qui servant testamentum eius et memores sunt mandatorum ipsius ad faciendum ea - Ps 102,17-18.

Konačno, potvrđeni su, premda rijetko, prijevodi u kojima se nalazi odnosna rečenica, što upućuje na sličnost hrvatske crkvenoslavenske inačice s latinskim tekstom:

(4) a. plačimb prêdb g(ospode)mb iže ni estb stvorilb Lob iže ni e(stb) stv(o)ril' Par iže ni e(st') stv(o)ril' Fr; iže ny estb ştvorilı Sin

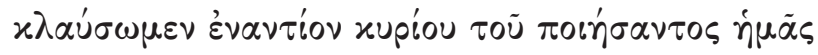
ploremus ante Dominum qui fecit nos - Ps 94,6;

b. êže pomenu sl(o)vo s(ve)toe svoe . eže imê ka avramu rabu svoemu Lob Par Fr; eže ïmje kъ avraamu Sin

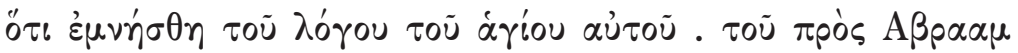

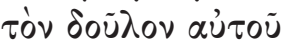

quoniam memor fuit verbi sancti sui . quod habuit ad Abraham puerum suum - Ps $104,42 .{ }^{8}$

\subsubsection{Nedeterminativni particip}

Grčki pravi pridjevski particip može biti i bez člana. U rečenici ovisno o kontekstu, može dolaziti u atributnom i u predikatnom položaju. U hrvatskom crkvenoslavenskom neočlanjenost bi mogla odgovarati neodređenosti sklo-

8 PASTRNEK 1903: 382, prema VALJAVEC 1889: 6. Usp. i Ps 17,34 u kojem se Lob i Par odnosnom rečenicom razlikuju od Fr i Sin koji imaju neodređeni particip. Zanimljivo je spomenuti asimetriju u kanonskim starocrkvenoslavenskim tekstovima prilikom prevođenja s grčkoga jezika: grčki particip prevodi se ili participom ili odnosnom rečenicom, dok se grčka odnosna rečenica uvijek prevodi samo odnosnom rečenicom (VEČERKA 1993: 69). S druge strane, $\mathrm{u}$ hrvatskome crkvenoslavenskom jeziku nije rijedak particip kojega nema ni u latinskome ni u grčkome predlošku (MIHALJEVIĆ 2009: 339). 
nidbenoga oblika. Ne determinirajući imensku riječ, particip se u određenom smislu osamostaljuje od nje dobivajući na većoj »predikativnosti«.

$N P / P N($ imenica + particip, particip +imenica): poput pridjeva, kada sročni particip u grčkom stoji s beščlanskom imenicom, katkada prema položaju nije moguće reći je li riječ o atributnoj ili predikatnoj uporabi. Uobičajen je obrazac NP. Zanimljivo je da u primjeru 5 hrvatskoglagoljski participi svojom neodređenošću (tj. jednostavnim oblikom) bolje prate predložak nego kanonski Sinajski psaltir u kojem je prvi particip u složenom obliku. U $5 a$ mogla bi biti riječ o participu u četvrtom atributnom položaju u kojem beščlanski particip dolazi uz beščlansku imenicu, a u drugom $(5 b)$, ako se ne shvati atributno, o participu u drugom predikatnom položaju u kojemu beščlanski particip stoji iza beščlanske imenice. Hrvatskoglagoljski aktivni particip u $5 b$ (tae) za predložak ima grčki particip u mediopasivnom obliku, dok je u latinskom također particip: ${ }^{9}$

(5) a. i bihь êko č(lovê)kb ne sliše i nê imee v ustehь svoihь obličeniê Lob sliše ... imêe Par deest Fr; slyšjęi ... imy Sin

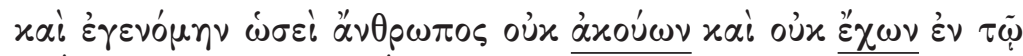

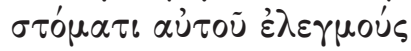

et factus sum sicut homo non audiens et non habens in ore suo redargutiones - Ps 37,15;

b. i b(i)si sr(bd)ce moe êko vos'kb tae po s'rêdê č'rêva moego Par Lob Fr; taje Sin

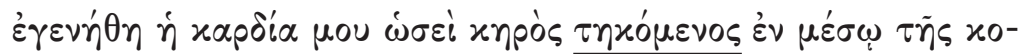

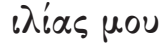

factum est cor meum tamquam cera liquescens in medio ventris mei - Ps 21,15 .

U primjeru 6 starocrkvenoslavenski ima neodređeni oblik participa, dok hrvatski crkvenoslavenski ponegdje ima određeni, što znači da se grčka neodređenost (izostanak člana) ne može u potpunosti poistovjetiti s (hrvatskom) crkvenoslavenskom neodređenosti sklonidbe:

(6) i godê budetb $b(o g) u$ pače telca ûna rogi izdêûca i pažnohti Lob iz'dêûcago Par deest Fr; izdjejošta Sin

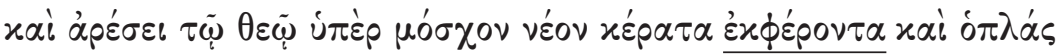

9 U primjeru $5 a$ PsSin, međutim, i bez prave potpore u grčkom ima slijed dvaju atributnih participa u određenom i neodređenom obliku, vidi VEČERKA 1961: 40. BOYER 1984: 167 se ne bavi funkcijom beščlanskih participa u ovom obrascu. 
et placebit Deo super vitulum novellum cornua producentem et ungulas - Ps 68,$32 ;^{10}$

Isto potvrđuje i primjer 7 u kojem se se svi izvori slažu u izboru određenoga oblika participa za grčki beščlanski particip: ${ }^{11}$

(7) gl(a)sь g(ospodb)nь skrušaûĉago kedri, i skrušitb g(ospod)b kedri livan'skie Lob Par deest Fr; sъkrušajoštaago Sin

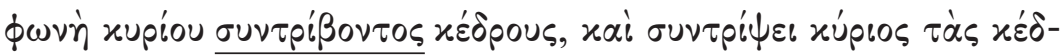

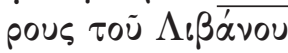

vox Domini confringentis cedros et confringet Dominus cedros Liba$\mathrm{ni}-\mathrm{Ps} 28,5$.

Gornji primjer zanimljiv je i stoga što u hebrejskom originalu navedeni beščlanski particip ima ulogu samostalnoga predikata, kakav se ponegdje na grčki prevodi indikativom prezenta, kao npr. u Ps 18,12 (usp. SAILHAMER 1991: 111, 115). U crkvenoslavenskom se prenosi određenim oblikom participa.

\subsubsection{Predikatni particip}

$P$ (particip kao predikatni pridjev) dolazi u predikatnom položaju, u nominativu, s veznim glagolom biti ili bez njega:

(8) niĉ i bolê esmь azь Lob Par deest Fr; Sin

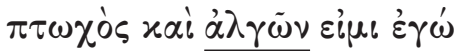

ego sum pauper et dolens - Ps 68,30.

ANP (član+imenica+particip). Particip u ovom obrascu očekivaniji je s pasivnim participima.

\subsubsection{Poimeničeni particip}

U grčkom su jeziku dva osnovna obrasca poimeničenoga participa: determinativni (3.1.2.1.) odnosno grčki particip s članom te nedeterminativni (3.1.2.2.), beščlanski particip.

${ }^{10}$ Usp. i Ps 28,$7 ; 100,4 ; 103,1-6 ; 104,32$.

${ }^{11}$ Usp. Ps 28,$9 ; 36,7 ; 57,8 ; 71,6 ; 73,19 ; 77,8 ; 88,8 ; 101,8 ; 118,176 ; 135,3-4$. U Ps 90,5-6 u slijedu dvaju participa u PsLob i Fr drugi oblik je neodređeni. 


\subsubsection{Determinativni particip}

$A P$ (član+particip): grčki particip s članom prevodi se kao hrvatski crkvenoslavenski poimeničeni pridjevski particip koji ima imenske sintaktičke uloge i u pravilu je u određenom obliku (usp. u starocrkvenoslavenskom VEČERKA 1993: 66; VEČERKA 1961: 12):

(9) utvrdilı estb g(ospod)b m(i)lostı svoû na boeĉih se ego Lob Par Fr; boję̌stiihs Sin

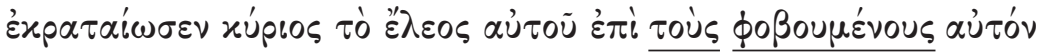
corroboravit misericordiam suam super timentes se - Ps 102,11. ${ }^{12}$

Uz poimeničene participe u psaltiru često dolazi kvantifikator $v b s b(\pi \tilde{\alpha} \varsigma) .{ }^{13}$

Samo katkada poimeničeni hrvatski crkvenoslavenski participi mogu biti i u jednostavnom, neodređenom obliku, ali i tu ima razlika među spomenicima (npr. PsFr u primjeru 10 sadrži određeni oblik):

(10) b(la)ž(e)nь razumevae na niĉa i na uboga Lob razumêvae Par $r(a) z(u) m(\hat{e})$ vaei $\mathrm{Fr}$; razumêvaję Sin

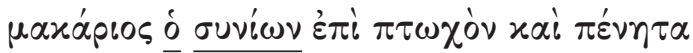

beatus qui intellegit super egenum et pauperem - Ps 40,2. ${ }^{14}$

Izvorni je smisao ovoga participa u grčkom ( $\delta$ ouvi $\omega v)$ kao i u hebrejskom $\mathrm{u}$ funkciji subjekta u imenskom predikatu, u rečeničnom redoslijedu predikat - subjekt. Moguće je da je u crkvenoslavenskim spomenicima u kojima je neodređeni oblik particip bliži nedeterminativnoj funkciji.

12 Usp. i: Ps 15,$5 ; 17,49 ; 21,26 ; 30,24 ; 32,15 ; 70,4 ; 70,11 ; 93,2 ; 98,6 ; 100,5 ; 106,23-24 ; 108,20$; 118,$157 ; 128,7$. Primjeri s mogućom haplografijom složenoga oblika u Sinajskom psaltiru: Ps 14,4 (nom sg. tipa jady); Ps 88,42 (nom.pl. na -i): Ps 17,40; 30,7; 91,12; 118,118; 118,158 $($ eje $>$ e). Također o haplografiji ili haplologiji bi mogla biti riječ u nominativu jednine i množine kanonskoga spomenika: Ps 5,12; 9,11; 120,4 (VEČERKA 1961: 21-22). U Ps 68,37 se međutim naši spomenici razlikuju (lûbeĉe Lob lûbeĉei Par).

${ }^{13}$ Usp. u grčkom GAUTHIER 2009: 54.

${ }^{14}$ U neodređenim, imenskim oblicima u PsSin (Ps 21,27; 43,5; 68,13; 93,20; 108,29; 134,6-7) te u Kločevu glagoljašu Večerka nalazi priložni vezani particip (prijelazni particip) za grčki particip s članom (VEČERKA 1961: 141). Međutim, osim u Ps 43,5 u kojemu sva tri psaltira prate PsSin, Ps 21,27 i 108,29 imaju određene oblike, u Ps 68,13 i 93,20 određeni oblik je u PsLob, a u 134,6 u PsFr. Za Ps 30,19; 54,20 u PsSin Večerka navodi da nije posve jasno je li riječ o neodređenim ili o složenim, ali stegnutim oblicima. U hrvatskoglagoljskim psaltirima u prvom slučaju (Ps 30,19) stoje određeni oblici. U drugom (Ps 54,20) PsLob i Par prate latinsku odnosnu rečenicu, dok Fr ima oblik sii što bi oboje moglo govoriti u prilog složenim oblicima i u PsSin. 
Svi hrvatskoglagoljski psaltiri svojom određenošću razilaze se od kanonskoga spomenika u sljedećem primjeru:

(11) g(ospod)i čto se umnožiše stužaûceei mi Lob Par Fr; sъtožajošte mi Sin

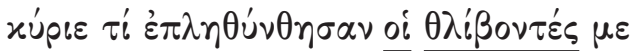

Domine quid multiplicati sunt qui tribulant me - Ps 3,2. ${ }^{15}$

Kao što je ranije rečeno, Miklošič je utvrdio da kad se ispred dva participa u grčkom nalazi zajednički član, prvi se u crkvenoslavenskom prevodi određenim, a drugi neodređenim oblikom. To se jasno vidi u primjerima $12 a$ i $12 b$. U $12 b$ pak Sinajski psaltir određenim oblikom drugoga participa prati grčki predložak koji određuje particip članom (VEČERKA 1961: 24):

(12) a. i nenavideĉei me ešutb pomizâ̂ce očima Lob Par deest Fr; nenavidjęciï ... pomizêjoce Sin

oi $\mu$

qui oderunt me gratis et annuunt oculis - Ps 34,19. ${ }^{16}$

b. sazdavi edin'nê $\mathrm{sr}(\mathrm{bd}) \mathrm{ca}$ ihь, i razumevae vsa dêla ihь Lob sz'dav'i ... razumêvae Par saz'davei ... razumêvae Fr; sozъdavy ... razumêvajęi Sin

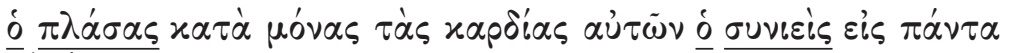
$\tau \dot{\alpha}$ हैp $\alpha \alpha \dot{u} \tau \tilde{\omega} \nu$

qui finxit singillatim corda eorum qui intellegit omnia opera illorum - Ps 32,15.

U $13 a$ oba su hrvatska crkvenoslavenska participa u određenom obli$\mathrm{ku}$, za razliku od starocrkvenoslavenskoga (kanonskoga) u kojem je drugi, u skladu s Miklošičevim pravilom, neodređen. U $13 b$ pak Lobkovicov se psaltir u neodređenosti drugoga oblika slaže sa Sinajskim psaltirom, za razliku od Pariškoga i Fraščićeva psaltira u kojima je drugi particip u određenom obliku:

(13) a. obeĉaitei vzdadite g(ospod)ub(og)un(a)š(e)mu, vsi suĉe okrstь prinosite dari strašnomu ot'emluĉumu d(u)hь knêzb Lob straš ’nomu i otemlûcumu Par deest Fr; strašbnumu i otъemljoštû Sin

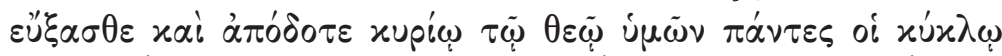

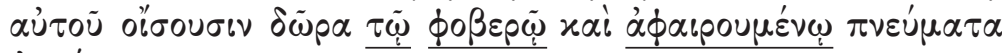
apxóv $\tau \omega \nu$ Ps $75,12-13$

\footnotetext{
${ }^{15}$ Usp. i Ps 24,10; 72,27; 68, 21.

${ }^{16}$ Usp. i Ps $48,7$.
} 
vovete et reddite Domino Deo vestro omnes qui in circuitu eius adferent munera terribili - Ps 75,12;

b. b(la)ž(e)ni hranêceei sudb, i tvorecee pravdu va vsako vr(ê)me Lob h'raneĉei ... tv(o)reĉei Par; hraneĉei ... tv(o)r(e)ceei Fr hranjęçei ... tvorjęce Sin

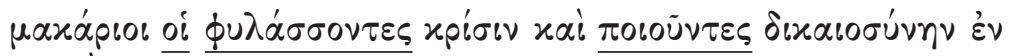
$\pi \alpha \nu \tau i$ ralp $\bar{i}$

beati qui custodiunt iudicium et faciunt iustitiam in omni tempore - Ps 105,3.

U primjeru 14 moguće je pretpostaviti da je poimeničeni particip u predikatnoj funkciji:

(14) êko ti esi istr'g'i me is čreva . upvanie moe ot sascu matere moee Lob Par esi istrgei Fr; $t$-y-strbgoi Sin (add. esi Pog Bon)

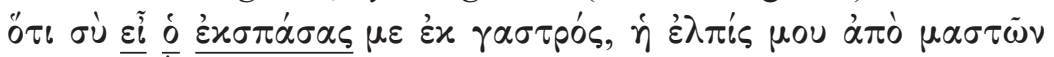
$\tau \tilde{\eta} s \mu \eta \bar{\tau} \rho \dot{s} \overline{\mu o v}$

quoniam tu es qui extraxisti me de ventre, spes mea ab uberibus matris meae - Ps $21,10 .^{17}$

Osim poimeničenim participom, u hrvatskoglagoljskom se psaltiru grčki particip s članom $(A P)$ katkad prenosi: odnosnom rečenicom sa iže $(15 a)$, imenicom (15b), finitnim oblikom (15c). Ipak, primjer $15 b$ vjerojatno govori u prilog drugom grčkom tekstovnom čitanju, dok je u $15 c$ oblik stvori mogu-

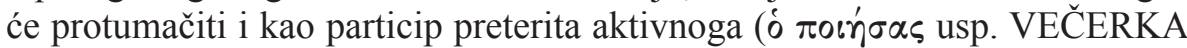
1961: 18):

(15) a. nê budi iže živêt' Lob iže živet' Par deest Fr; iže živeţ Sin $\mu \dot{\eta} \tilde{\varepsilon} \sigma \tau \omega \dot{o} x \alpha \tau o \omega x \tilde{\omega} \nu$

non sit qui inhabitet - Ps 68,26; ${ }^{18}$

b. ponošahu mnê vrazi moi Lob vr(a)zi Par Fr; vradzi Sin

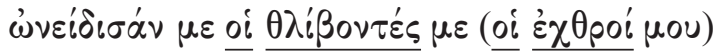

exprobraverunt mihi qui tribulant me - Ps 41,$11 ;{ }^{19}$

c. onemehь i nê otvrestı ust' moihь, êko ti stvori Lob Par; Sin; stv(o)ri $\mathrm{Fr}$

\footnotetext{
${ }^{17}$ Usp. i Ps 38,10 u primjeru $15 c$.

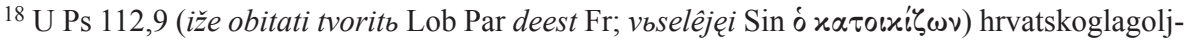
ski se psaltiri razlikuju od PsSin.

${ }^{19}$ Za razliku od hrvatskoglagoljskih spomenika, PsSin ima imenicu i u Ps 70,11 (izbavêi Lob izb(a)vei Par deest Fr; izbavbnika Sin ó puóuعvos qui eripiat).
} 


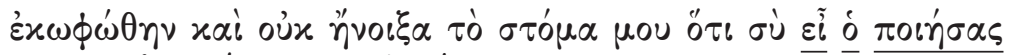

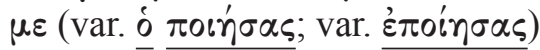

obmutui et non aperui os meum quoniam tu fecisti - Ps $38,10 .^{20}$

3.1.2.1.1. Ostali prijevodni predlošci. Poimeničeni participi u hrvatskoglagoljskom psaltiru dolaze i kao prijevodi drugih konstrukcija u grčkom jeziku, npr. člana s prilogom (usp. VEČERKA 1961: 18-19):

(16) položil ni esi ponošeniû susedomb $\mathrm{n}(\mathrm{a})$ šimb podražaniû i poruganiû sucimb okrstb n(a)sb Lob sucim'oh(rbst)b Par suĉimb oh(r'st)b Fr; sQštiimb okrъstr Sin

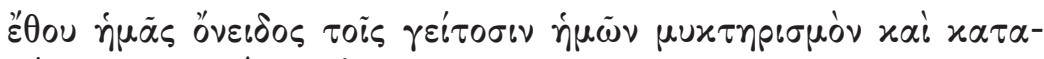

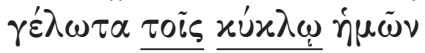

posuisti nos obprobrium vicinis nostris subsannationem et derisum his qui in circuitu nostro - Ps 43,14.

Ipak, moguće je da particip iz primjera 17 dolazi prema participskom čitanju u nekim drugim grčkim recenzijama Septuaginte, a ne prema imenici $\tau \tilde{\omega} \nu \stackrel{\varepsilon}{\chi} \theta \rho \tilde{\omega} \nu$ :

(17) vznêse desnicu stužaûcihb emu Lob stužaûcih' Par Fr; ştožajoštihъ emu Sin

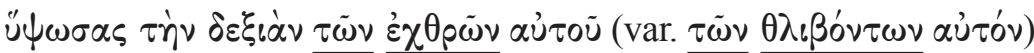
exaltasti dexteram deprimentium eum - Ps $\overline{88,43}$.

\subsubsection{Nedeterminativni particip}

$P$ (sam particip u imeničkoj ulozi): neki grčki beščlanski participi prevode se u hrvatskom crkvenoslavenskom katkada neodređenim, a katkada određenim oblicima participa. Raščlanjujući Sinajski psaltir Večerka je uočio da su takvi poimeničeni participi češći u kosim padežima nego u nominativu. Primjeri $18 a$ i $18 b$ su u nominativu, a primjer $18 c$ u genitivu:

(18) a. g(ospod)b s n(e)b(e)se priniče na s(i)ni č(lovêča)skie, videti aĉe estb razumevae ili vziskae b(og)a Lob razumêvae ... v'ziskae Par razumêvaei ...v vz(i)skae Fr

\footnotetext{
${ }^{20}$ Słoński i Angelova smatraju stvori finitnim oblikom aorista. Angelova još primjećuje da je rastavljena grčka veza u starocrkvenoslavenskom jedinstvena. Večerka se pita nije li možda riječ o prvom aktivnom participu preterita u stegnutom obliku (VEČERKA 1961: 18).
} 


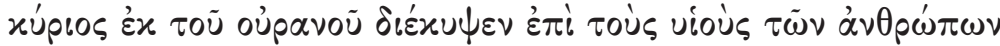

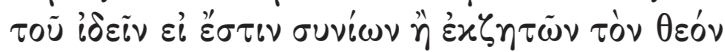

Dominus de caelo prospexit super filios hominum ut videat si est intellegens aut requirens Deum - Ps 13,2;21

b. izgonêcei me ninê obidu me Lob iz'goneĉei Par Fr; izgonjęštei Sin

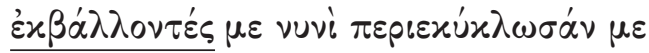

proicientes me nunc circumdederunt me - Ps 16,11,22

c. i sp(a)se e iz' ruki nenavideĉih' Fr Lob Par; Sin

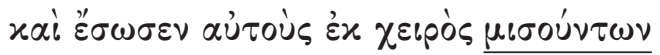

et salvavit eos de manu odientium - Ps 105,10. ${ }^{23}$

Osim participa u hrvatskoglagoljskom psaltiru nalazimo i pridjev, dok je u PsSin kao i u grčkom particip:

(19) da potrêbêt se ots knigb životnihb Lob živ(o)tnih' Par deest Fr; živoštihъ Sin

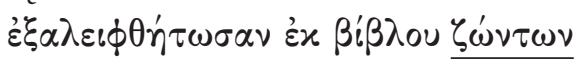

deleantur de libro viventium - Ps 68,29.

\subsection{Glagolske uporabe}

Među glagolskim participima moguće je razlikovati: priložni particip (3.2.1.), perifrastični particip (3.2.2.), particip samostalnoga predikata (3.2.3.) te dopunski particip (3.2.4.). Glagolski participi u grčkom su jeziku bez člana, a na hrvatski crkvenoslavenski prevode se neodređenim oblicima.

\subsubsection{Priložni particip}

U ovoj ulozi pojavljuju se u psaltiru grčki particip prezenta, perfekta i aorista, bez člana, kojima u crkvenoslavenskom prijevodu odgovaraju neodređeni oblici aktivnoga participa prezenta i prvoga aktivnoga participa preterita. Oblici priložnoga vezanoga participa (3.2.1.1.) slažu se sa rečeničnim

${ }^{21}$ U Ps 14,2 primjetljivo je kolebanje između neodređenih i određenih oblika (hode bes poroka

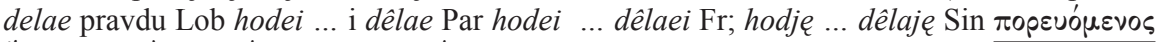

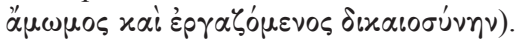

${ }^{22}$ Usp. i Ps 52,2; 52,4; 69,4; 100,6-7 (usp. VEČERKA 1961: 20).

${ }^{23}$ Usp. i Ps 8,$3 ; 23,6 ; 24,8 ; 26,12 ; 26,13 ; 27,3 ; 30,14 ; 33,17 ; 36,1 ; 43,16-17 ; 47,7 ; 51,7 ; 55,14$; 57,$6 ; 62,12 ; 63,3 ; 72,20 ; 77,42 ; 93,16 ; 100,3 ; 106,36$ (usp. VEČERKA 1961: 20). 
subjektom u nominativu te se podređuju rečeničnom predikatu, dok se onaj priložnoga apsolutnoga participa (3.2.1.2.) slaže u padežu sa svojim subjektom smještenim unutar apsolutne konstrukcije, u grčkom u genitivu te u crkvenoslavenskom $u$ dativu, i preko nje je podređen rečeničnom predikatu.

\subsubsection{Priložni vezani particip}

3.2.1.1.1. Participium coniunctum karakteristika je grčkoga stila, kako klasičnoga tako i koine, u kojemu ovaj nominativni beščlanski particip ovisno o značenju i kontekstu ima vrijednost priložnih istosubjektnih surečenica. ${ }^{24}$ Primjeri u Septuaginti ponešto se od toga razilaze budući da u hebrejskom particip aktivni ima drugačije uloge od grčkoga priložnoga vezanog participa. U hebrejskom predlošku nema nijedne istovjetne strukture koja bi se u grčkom mogla izraziti priložnim vezanim participom, nego je on češće prevoditeljski odabir u slučaju dviju koordiniranih surečenica, blisko povezanih značenjem koje opisuju neku radnju ili dijelove iste radnje, združenih u grčkom $\mathrm{u}$ jednu surečenicu u kojoj je jedan od predikata particip podređen drugome izraženom u finitnom obliku. Takvi glagolski obrasci značenjem ne pristaju u uobičajene uloge priložnih participa. S druge strane, doslovna metoda prijevoda koja traži i formalnu istovrijednost nije osobito povoljna za takve izraze te je istosubjektni priložni particip relativno neuobičajen u Septuaginti (AEJMELAEUS 1982: 384). ${ }^{25} \mathrm{O}$ glagolskom karakteru sljedećih primjera govore i latinske paralele koje u nekim slučajevima imaju particip (na jednom mjestu pridjev) koji je moguće protumačiti priložno, a u drugima zavisnu surečenicu priložnoga značenja.

Vremensko značenje izražava se u hrvatskom crkvenoslavenskom participom prezenta istovremenim radnji predikata (20a) te participom preterita prijevremenim $(20 b):^{26}$

(20) a. sede na brata svoego klevetaše Lob sêde Par Fr; sêdję Sin

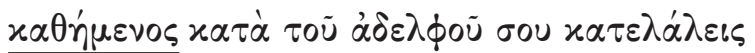
sedens adversus fratrem tuum loquebaris - Ps 49,20;

\footnotetext{
${ }^{24}$ Naziva se i particip prijelazne odredbe (VEČERKA 1961: 116).

${ }^{25}$ Prema AEJMELAEUS 1982: 385, 387 particip u ulozi priložnoga vezanoga participa kao prijevod hebrejskoga participa pojavljuje se tek jednom ili nekoliko puta u pojedinim knjigama grčke Septuaginte, s izuzetkom jedanaest primjera u psalmima, osam u Jeremiji, šest u Izaiji $\mathrm{i}$ pet u Malim prorocima.

${ }^{26}$ Usp. i Ps 34,$11 ; 47,6 ; 48,21 ; 70,21 ; 101,11$.
} 
b. všadb v na isp(o)vêm se g(ospode)vê Lob v'š'd' Par deest Fr; $v b$ šed $_{b} \mathrm{Sin}$

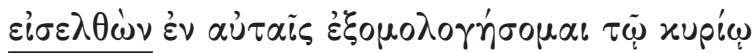

ingressus in eas confitebor Domino - Ps 117,19.

Načinsko značenje participa prezenta objašnjava ili definira radnju glavnoga glagola:

(21) vsk(uû) setue hoždu Lob sêtue Fr; sêtuję Sin

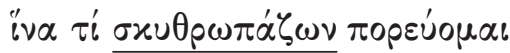

quare tristis incedo - Ps 42,2.

Paronomastičkim participom s finitnim oblikom istoga glagola ili glagola istoga ili sličnoga značenja, tj. povezivanjem dvaju oblika iste osnove odnosno dvaju oblika istoga značenja naglašava se značenje glagola. Iako se paronomastički participi pojavljuju u izvornim grčkim tekstovima, njihovo gomilanje, te osobito uporaba participa umjesto grčkom jeziku svojstvenije srodne imenice smatra se hebreizmom. Grčki vezani priložni particip ovdje u pravilu prevodi hebrejski infinitiv apsolutni):

(22) iduce idêhu i plakahu se . vmêtaûce semena svoê . grêduĉe že pridutb s radostiû vzemlûce rukovêti svoe Lob iduĉe idêhu ... greduĉe že pridut' Par hodeĉe že hoždahu ... greduce že pridut' Fr; hodjęštiï hoždaaho ... grjędošte že prïdǫtъ Sin

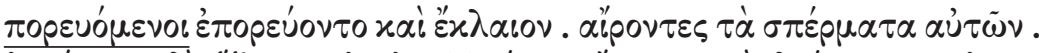

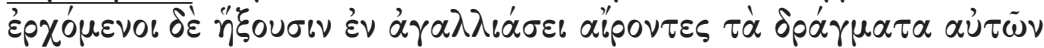
euntes ibant et flebant . portantes semina sua . venientes autem venient in exultatione portantes manipulos suos - Ps 125,6 (AEJMELAEUS 1982: 386-387; RUBIO 2009: 222).

Uzročni smisao izražen preteritom ili prezentom često prethodi predikatu. Tako se i slijedom rečeničnih sastavnica izražava da uzrok radnje prethodi radnji:

(23) i na gospoda upvae ne iznêmogu Lob Par Fr; upъvaję Sin

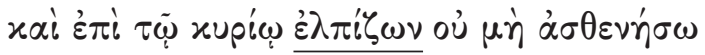
et in Domino sperans non infirmabor - Ps 25,1.

Smisao svrhe je u participu prezenta, iza glavnoga glagola:

(24) az že postavlenь esmь c(êsь)rb ot nêgo . nad' sionomb goroû s(ve)toû ego . vzveçae povelênie gospodne Lob v'zvêcae Par vaz'vêšcae Fr; vbzvêstaję Sin 


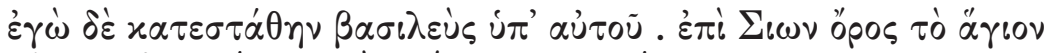

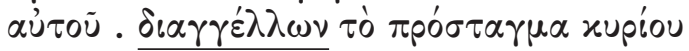

ego autem constitutus sum rex ab eo . super Sion montem sanctum eius . praedicans praeceptum eius - Ps 2,6-7.

U grčkom nema primjera s namjernim značenjem, dok su infinitivi namjere i prijedložni izrazi tvoreni od عis s akuzativom vrlo brojni, što je moguće tumačiti i utjecajem hebrejskog infinitiva konstruktnoga s prijedlogom i bez njega te imenskih prijedložnih izraza (o infinitivu namjere u starocrkvenoslavenskom psaltiru usp. KURZ 1937-1938: 292-297, PASTRNEK 1903: 370375, 383-384, u hrvatskom crkvenoslavenskom TURKALJ 2013). Razlog uporabe infinitiva za iskazivanje namjere leži i u samoj apstraktnosti infinitiva kojim se i inače u grčkom iskazuje radnja koja se osjeća tek kao naumljena i moguća, nasuprot onoj stvarnoj koja bolje pristaje faktičnoj naravi participa (DUKAT 2003: 331).

Upravni govor uvodi se participom glagole, glagolûce ( $\left.\lambda \dot{\varepsilon} \gamma \omega \nu, \lambda \varepsilon^{\prime} \gamma o v \tau \varepsilon \varsigma\right)$ :

(25) s'v(ê)ĉaše v' k(u)p' gl(agol)ûce Par svêĉaše ... gl(agol)uce $e^{27} \mathrm{~b}(\mathrm{og}) \mathrm{b}$ ostavil' i estı Lob deest Fr; sbvještašję ... gl(agol)jošte Sin

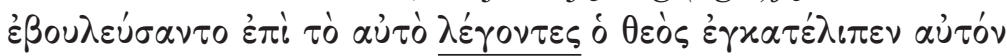
consilium fecerunt in unum, dicentes: Deus dereliquit eum - Ps $70,10-11$.

U sljedećem odlomku (primjer 26) primjetljiva je razlika među crkvenoslavenskim spomenicima. Dok Fraščićev psaltir participskim prijevodom slijedi Sinajski, odnosna rečenica u Lobkovicovu i Pariškom psaltiru mogla bi

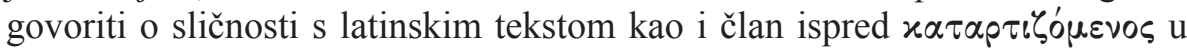
nekim zapadnim grčkim recenzijama:

(26) bogь [prepoêsai me siloû . i položi neporočan' put' moi .] svr'šae nozê moi êko eleni i na visokih' postav'lae me . naučae rucê moi na branь . i položi êko luk' mêden' miš'ci moei Fr [iže prepoêsa] ... iže svršaetb ... postavi iže naučaetb Lob Par; [prêpoêsajęi] ... şvrbšaje ... postavlêję ... naučaję Sin

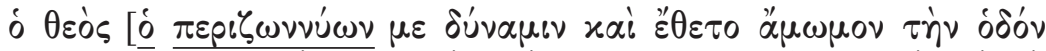

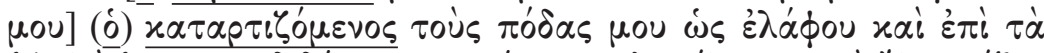

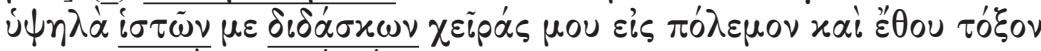

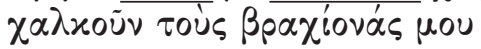

Deus [qui praecingit me virtute et posuit inmaculatam viam meam] qui perfecit pedes meos tamquam cervorum et super excelsa statuens

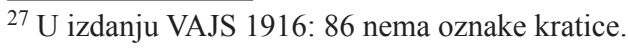


me qui doces manus meas in proelium et posuisti arcum aereum brachia mea - Ps 17,33-35.

R. Večerka (VEČERKA 1961: 129; VEČERKA 1996: 204) participe u tom odlomku Sinajskoga psaltira tumači kao primjer prijelaznoga participa u labavijem odnosu prema susjednoj rečenici. U tumačenju ne uzima u obzir dio 33. retka (unutar uglatih zagrada). Između participa i finitnoga glagola mogu se umetati parataktički veznici što govori u prilog labavu odnosu sporednoga predikata prema susjednoj rečenici. U većini slučajeva kao veznik se upotrebljava $i$, kao u primjeru 26 iza participa (naučae) i ispred finitnoga glagola (položi). Međutim, ako se u cjelinu uzme i prvi particip (prêpoêsai) u atributnom položaju i ostali bi se participi u nizu mogli shvatiti atributno, kako ih shvaćaju spomenici koji slijede latinski predložak (Lob, Par). U prilog glagolskom tumačenju tih grčkih participa mogli bi govoriti hebrejski finitni

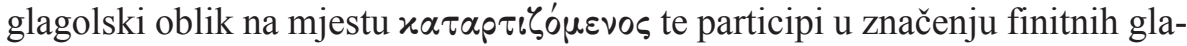

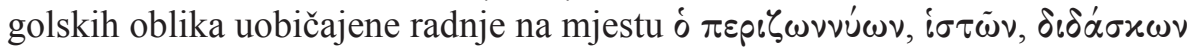

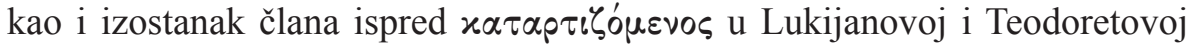
recenziji.

U crkvenoslavenskom, za razliku od suvremenih slavenskih jezika, kao i u starijim spomenicima drugih slavenskih jezika, zavisni priložni participi bili su u znatno većoj mjeri sintaktički samostalni, tako da se mogu smatrati stvarnim »sporednim predikatima« (VEČERKA 1996: 199).

3.2.1.1.2. Ostali prijevodni predlošci. Vezani participi u hrvatskoglagoljskom psaltiru potvrđeni su i kao prijevodi drugih konstrukcija u grčkom pred-

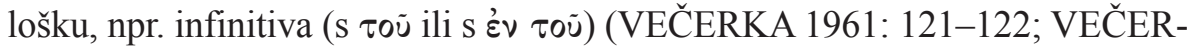
KA 1996: 180), što pokazuje primjer 27a. Istovremenost se kako u grčkom originalu tako i u crkvenoslavenskom prijevodu izražava infinitivnom vremenskom konstrukcijom (TURKALJ 2013: 148-150). U primjerima $27 b$ i $27 c$, umjesto očekivanoga infinitiva, za konstrukciju $\varepsilon$ v s dativom infinitiva u vremenskom značenju pojavljuje se jednostavni priložni oblik participa. U $27 c$ hrvatskoglagoljski se spomenici razlikuju u određenosti od PsSin koji za razliku od njih ima određeni oblik participa poimeničenoga smisla:

(27) a. tako vspoju imeni tvoemu va veks v(ê)ka, vzdae m(o)l(i)tvi moe d(ь)n' d(ь)nê Lob Par Fr; vbzdaje Sin

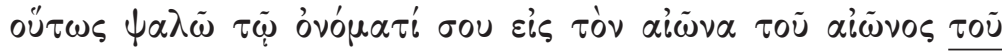

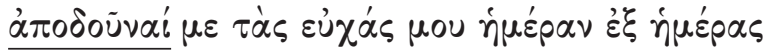

sic psalmum dicam nomini tuo in saeculum saeculi ut reddam vota mea de die in diem - Ps 60,9; 
b. plakahom se pomenuvše sionь Lob Par pom(e)nuv'še Fr; pomjęnovъše Sin

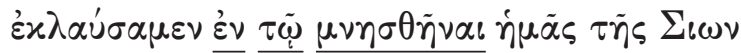

flevimus cum recordaremur Sion - Ps 136,1;

c. ide umirae ne ostavit li sego Lob Par Fr; umirajęi Sin

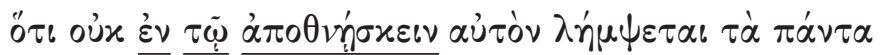

quoniam cum interierit non sumet omnia - Ps 48,18.

Primjer 28 s grčkim finitnim oblikom u aoristu u literaturi se tumači dvojako, kao samostalni predikatni particip i kao priložni vezani particip odnosno, particip prijelazne odredbe kako ga naziva Večerka (VEČERKA 1961: 96). U PsPar je određeni oblik participa poimeničenoga smisla:

(28) êko stvorilı esi sud' moi i pru moû, sede na prestolê sudei pravdu Lob sêde Fr sêdei Par; sêdję Sin

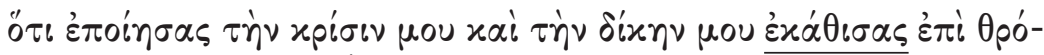

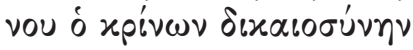

quoniam fecisti iudicium meum et causam meam sedisti super thronum qui iudicas iustitiam - Ps 9,5.

\subsubsection{Priložni apsolutni particip}

3.2.1.2.1. Među apsolutnim participima u hrvatskom crkvenoslavenskom prepoznatljiv je dativ apsolutni. Njime je moguće izraziti iste priložne nijanse kao i zavisnim priložnim participima, s razlikom što značenje namjerne rečenice može kod dativa apsolutnoga izostati. U hrvatskoglagoljskom psaltiru dativom apsolutnim izražava se vremensko (29), pogodbeno (30) i uzročno značenje (31). U primjerima s vremenskim i pogodbenim značenjem slavenski je dativ apsolutni učestala prijevodna istovrijednica grčkoga genitiva apsolutnoga:

(29) eda kogda pohitit' êko 1(a)v' d(u)šu moû . ne suĉu iz'bav'lâuĉmu

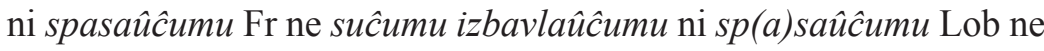
suĉmu iz'b(a)vlaûcumu ni sp(a) sâ̂cumu Par; nï ĉjo izbavlajoĉtumu ni sъpasajoĉumu Sin

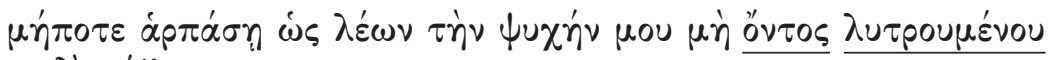
$\mu \eta \delta^{\prime} \varepsilon \sigma \omega_{\zeta}^{\prime} \zeta_{0 \nu \tau o \varsigma}$

nequando rapiat ut leo animam meam dum non est qui redimat neque qui salvum faciat - Ps 7,3; 
(30) davšu tebê imь zbêrut se . otvraĉ'šu že tebê ruku tvoû . vsačaska napl'nêt se bl(a)gosti . otvraĉu (!) že tebê licê tvoe smetut se . otimeši d(u)hь tvoi iceznut' Lob dav'šu že t(e)bê ... otvrz'šu t(e)bê $\ldots o^{t} v r a \hat{c} ' s ̌ u$ že $t(e) b e \hat{e}$ Par $d a v$ 'šu že $t(e) b e \hat{e} \ldots o t v r$ 'zšu že $t(e) b e$ ... ot vrašt'šu že t(e)bê Fr; davъšŝ̀ tebê ... otъvrbzъšn̂ že tebê ... otzvraštzšûu že tebê Sin

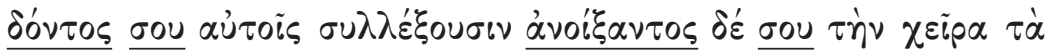

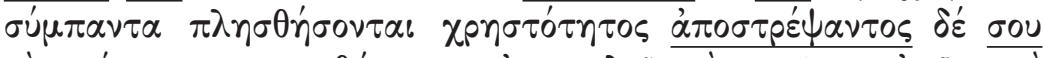

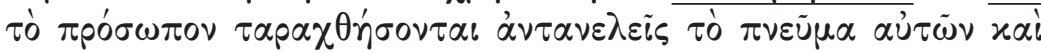

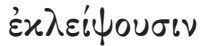

dante te illis colligent aperiente te manum tuam omnia implebuntur bonitate avertente autem te faciem turbabuntur auferes spiritum eorum et deficient et in pulverem suum revertentur - Ps 103,28-29.

3.2.1.2.2. Ostali prijevodni predlošci. U uzročnim primjerima na dva mjesta u grčkom originalu stoji prijedložni izraz à $\pi$ ó s članskim infinitivom (gerundom) dok je u latinskom vremenska rečenica, uvedena istovremenim veznikom dum: ${ }^{28}$

(31) a. êko umlčah' obet’šaše kosti moe . zovuĉu mi vasь danь Fr Par om. mi Lob; zovošte mi Sin

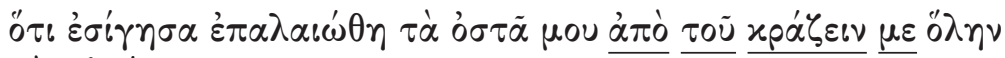
$\tau \dot{\eta} \nu \dot{\eta} \mu \dot{\varepsilon} \rho \alpha \nu$

quoniam tacui inveteraverunt ossa mea dum clamarem tota die - Ps 31,$3 ;{ }^{29}$

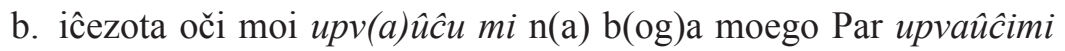
Lob deest Fr; upbvajQštû mi Sin

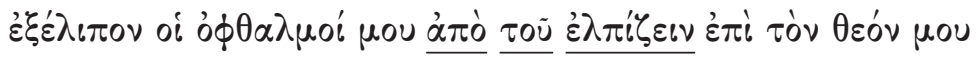
defecerunt oculi mei dum spero in Deum meum - Ps 68,4.

${ }^{28}$ VEČERKA 1961: 47. U podlozi grčkih fraza hebrejska je prijedložna konstrukcija sastavljena od prijedloga beth ('u') s infinitivom konstruktnim odnosno imenicom u uzročnom značenju. Osim vremenskoga značenja, grčka konstrukcija év $\tau \tilde{\omega}$ s infinitivom može imati i značenja sredstva i uzroka. Uzročna rečenica sa zane u Ps 104,12 i prijedložni izraz s ot u Ps 41,10 prijevodi su $\varepsilon$ ¿े $\tau \tilde{\varphi}$ s infinitivom odnosno imenicom (TURKALJ 2013: 148).

${ }^{29}$ Možda bi zovuĉu mi mogao biti shvaćen i vremenski, kao latinski dum clamarem. Najčešća uloga dativa apsolutnoga u kanonskim tekstovima je vremenska (STANISLAV 1933-1934: 8-10), a isto vrijedi i za hrvatski crkvenoslavenski jezik (MIHALJEVIĆ 2009: 339). Gotovo svi participi, bili priložni ili ne, barem drugotno su vremenski (WALLACE 1996: 624). 


\subsubsection{Perifrastični particip}

Prateći grčki tekst, u hrvatskoglagoljskom je psaltiru potvrđen neodređeni particip prezenta aktivnoga (prema grčkim participima prezenta i perfekta, bez člana) u spoju s finitnim oblicima glagola biti (prema pomoćnim glago-

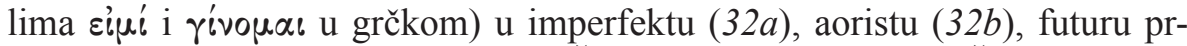
vom (32c) te u imperativu (33d) (VEČERKA 1993: 93-94; VEČERKA 1961: 70-71; DAMJANOVIĆ 2003: 157). Ovaj particip sročan je sa subjektom u nominativu:

(32) a. stoeĉe b(ê)hu nogi n(a)še . v dvorêh' i(eruso)limb Fr stoeĉe bêhu Lob Par; stojęšte bêaho Sin $\dot{\varepsilon} \sigma \tau \tilde{\omega} \tau \varepsilon \varsigma \underline{\hat{\eta}} \sigma \alpha \nu$ oi $\pi \dot{\delta} \delta \varepsilon \zeta \dot{\eta} \mu \tilde{\omega} \nu$

stantes erant pedes nostri - Ps 121,2;

b. bihomb veseleĉe se Lob bihom'veseleĉe se Fr Par; byhomъ veseljęšte sję Sin

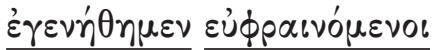

facti sumus laetantes - Ps 125,3;

c. id(obro) priem 'lûce b(u)dut' da vz'vês'tet'. êk(o) prav'g(ospod)ь b(og)b n(a)š' Fr dobro priemlûce budut' Lob dobro prieml'ûce budutb Par; dobroprijemljošte bodotı Sin

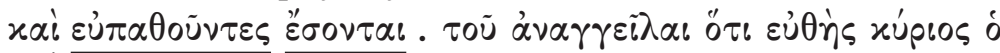
$\theta$ cós $\mu \mathrm{OU}$

et bene patientes erunt . ut annuntient quoniam rectus Dominus - Ps 91,15-16;

d. budêta uši tvoi vnem'lûci gl(a)sь m(o)l(i)tvi moee Fr budita ... vnêmlûci Lob budita ... vnem 'lûci Par; bodêta ... vъnemlošte Sin

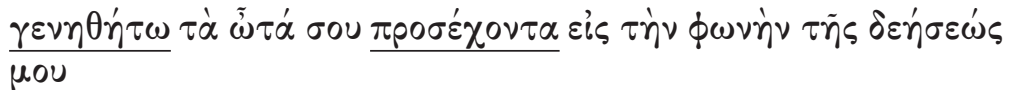
fiant aures tuae intendentes in vocem deprecationis meae - Ps 129,2.

Ovom se participskom tvorbom naglašava trajnost radnje (VEČERKA 1961: 82). Premda je u kanonske tekstove došla iz postklasičnoga grčkog, rabila se i neovisno o grčkom predlošku (VEČERKA 1961: 70-73). Gramatički i semantički jedinstvena, katkad se smatra opisnim oblikom. Protiv njezina poimanja kao analitičke odnosno višerječne cjeline glagolske paradigme govori uporaba aktivnih participa s finitnim oblikom glagola biti u višestrukom predikatu uz predikatne pridjeve. ${ }^{30}$

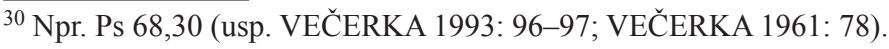




\subsubsection{Particip samostalnoga predikata}

U biblijskom grčkom particip može stajati i samostalno kao rečenični predikat $\mathrm{u}$ indikativu. ${ }^{31}$ Bez vremenske upute kakvu daje kopula, takav particip izražava isključivo sadašnjost.

Često je u crkvenoslavenskom teško dokučiti je li u pojedinim slučajevima riječ o participu samostalnoga predikata ili particip ima neku tješnju vezu s okolnim kontekstom ili je pak riječ o participu s glagolom biti. Mišljenja su o identitetu participa kao samostalnih predikata podijeljena. Dok im jedni posve poriču pripadnost sustavu starocrkvenoslavenskoga, smatrajući pojedine primjere pogreškama pisara i slučajnim ili namjernim prijenosom iz grčkoga jezika, drugi ih smatraju domaćim jezičnim sredstvom. O mogućem samostalnom predikatnom tumačenju govore primjeri iz kanonskih evanđelja u kojima se u varijantama usporedno pojavljuju finitni i participski glagolski oblici (VEČERKA 1961: 93-94).

Budući da u psaltiru nema mnogo slučajeva u kojima bi se grčki participi mogli tumačiti priložno, moguće je da se, unatoč tome što u crkvenoslavenskom samostalni participi teže punijem izražavanju dodavanjem kopule participu, određeni broj grčkih glagolskih nominativnih neodređenih participskih oblika u hrvatskom crkvenoslavenskom tumače kao samostalni predikati. Tomu u prilog govori i latinska paralela koja ima particip, a ne odnosnu rečenicu karakterističnu za primjere determinativnoga značenja, kao i položaj crkvenoslavenskoga neodređenoga participa u rečenici koji stoji samostalno u redoslijedu predikat - subjekt uobičajenom za hebrejsku rečenicu.

Međutim, čini se da je u hrvatskom crkvenoslavenskom primjetno popridjevljenje glagolskih participa. Iako samostalni predikati u hrvatskom crkvenoslavenskom dolaze u neodređenim oblicima, u primjerima $33 a$ i $33 b$ PsPar svojim odstupanjem u određenosti vjerojatno govori o drugačijem, poimeničenom shvaćanju:

(33) a. tvore m(i)1(o)sti g(ospod)' . i sudbi vsemb obidimimb Lob Fr tvorei Par; tvorję Sin

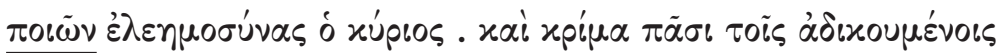
faciens misericordias Dominus . et iudicium omnibus iniuriam patientibus - Ps 102,6;

\footnotetext{
31 WALLACE 1996: 653. Rečenice s imenskim predikatom bez kopule u grčkome tekstu Biblije zastupljene su osobito u Starom zavjetu, pa ih se zajedno s onima u Novom zavjetu promatra kao sintaktičke hebreizme. Izvorno su dakle hebreizmi i primjeri koji se nalaze $u$ starocrkvenoslavenskim prijevodima s grčkoga, no u starocrkvenoslavenskome ih ipak nema mnogo jer se grčki nominalni predikat bez kopule znatno češće prevodi starocrkvenoslavenskim predikatom s kopulom (VEČERKA 1993: 141).
} 
b. b(og)b n(a)šb miluet' . hranê mladênce g(ospod)b Lob hranei Par deest Fr; hranję Sin

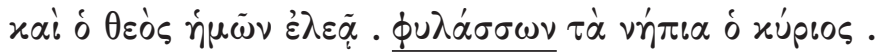

et Deus noster miseretur . custodiens parvulos Dominus . - Ps $114,5-6$.

U pojedinim slučajevima teže je razlučiti ima li particip ulogu samostalnoga predikata ili nekoga predikata sintaktički čvršće vezanoga uz rečenični kontekst, odnosno ulogu vezanoga priložnoga (prijelaznoga) participa povezanoga s nekim finitnim glagolskim oblikom (VEČERKA 1961: 93).

Za grčki particip samostalnoga predikata zabilježen je i hrvatski crkvenoslavenski finitni glagolski oblik, što je jasna potvrda da je u grčkom doista riječ o ovoj vrsti participa:

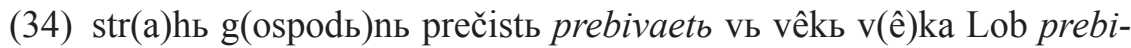
vaet' Par Fr; prêbivaetz Sin

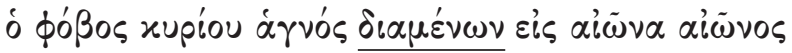

timor Domini sanctus, permanens in saeculum saeculi - Ps $18,10{ }^{32}$

Sljedeći primjer Večerka tumači na više načina: a) kao dvije imenske rečenice (bogb suditelb i (bogb) ne g'nêva navode), b) kao jednu rečenicu s predikatnom imenicom razvijenom trima atributnim pridjevima i s njima paralelnim participom (suditel' $p r(a) v(e) d a n$ 'i $k r(\hat{e}) p a k$ 'i tr'pêliv'i navode) te c) kao imensku rečenicu s prijelaznim participom (bogb (estb) suditelb, navode) (VEČERKA 1961: 97):

(35) b(og)b suditel' pr(a)v(e)dan' i kr(ê)pak' i tr'pêliv' i ne g'n(ê)va $n a-$ vode na vsak' d(a)nь Fr Par n'vode Lob; navodje Sin

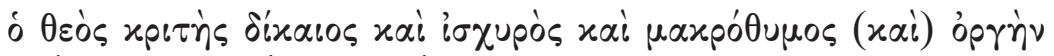

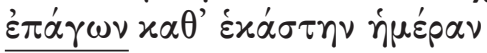

Deus iudex iustus et fortis et patiens numquid irascitur per singulos dies - Ps $7,12 .{ }^{33}$

U primjeru 36 između pridjeva (milostivb) i aktivnoga participa nalazi se glagol biti.

${ }^{32} \mathrm{U}$ prethodna dva retka, Ps $18,8-9$ na usporednim mjestima u retku dolaze neodređeni participi.

${ }^{33}$ Ps 34,6 (budi putь ihь tamanь i pl'zakь, i anĵ(e)lı g(ospodь)nь stužae imь) mogao bi govoriti u prilog tumačenju gornjega primjera kao samostalnoga predikata. O mogućnosti tumačenja Ps 34,6 kao samostalnoga predikata usp. VEČERKA 1961: 88-89. 
(36) b(ož)e ti m(i)l(o)st(i)vb bivaše im', i m'ĉae na v's(a)ka načinaniê ih' Par maĉae Lob; mbštaje Sin

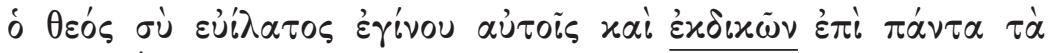
$\dot{\varepsilon} \pi \imath \tau \eta \delta \varepsilon \dot{u} \mu \alpha \tau \alpha \alpha \dot{\nu} \tau \tilde{\omega} \nu$

quoniam magnus es tu et faciens mirabilia tu es Deus solus - Ps $98,8 .^{34}$

Ovdje valja obratiti pozornost na red riječi. Da je redoslijed particip - pridjev, vjerojatan bi zaključak bio da je riječ o višečlanom imenskom predikatu, tj. o glagolu biti koji otvara mjesto i pridjevu i participu. No obratan redoslijed, pridjev - particip, te veznik $i$ koji se nalazi ispred participa upućuje na to da bi u crkvenoslavenskom valjalo govoriti o imenskom predikatu ( m(i)l(o)st(i)vb bivaše im') i o sekundarnom predikatu priložnoga participa m'çae (VEČERKA 1961: 78).

\subsubsection{Dopunski particip}

Ova vrsta glagolskoga participa dolazi s izravnim objektom, uz glagole osjećanja (verba sentiendi). Dio je konstrukcije tzv. dvostrukoga akuzativa: ${ }^{35}$

(37) i ne vidêh' prav(e)dnika os'tav'lena ni sêmene ego proseĉa hleba Par Lob $\operatorname{pr}(o) s(e) \hat{c} a$ Fr; prosjęça Sin

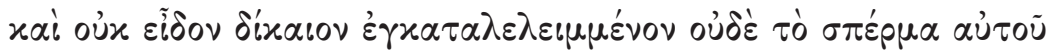

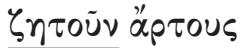

et non vidi iustum derelictum nec semen eius quaerens panes - Ps 36,25 .

\footnotetext{
${ }^{34}$ Neke primjere s participima iza pridjeva i glagola biti na primjeru Sinajskoga psaltira VEČERKA tumači kao složene predikate sastavljene od imenskoga predikata i sekundarnoga predikata (priložnoga participa). U Ps 85,10 svi hrvatskoglagoljski spomenici kao i istočni psaltiri imaju poimeničene oblike što vjerojatno ide u prilog njihovu atributnom shvaćanju (êko veli esi ti, tvorêi čudesa ti esi b(og)b edinь Lob t'vorei Par (tvoręi Pog Bon); i tv(o)rei

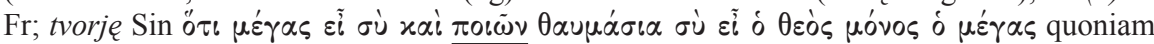
magnus es tu et faciens mirabilia tu es Deus solus).

${ }^{35}$ Neki autori particip u ovoj službi nazivaju predikatnim (npr. u grčkom MUSIĆ; MAJNARIĆ 1989: 236) jer nadopunjuje predikat. VEČERKA (1961: 57-64) govori o konstrukciji participa s akuzativom u crkvenoslavenskom jeziku kao o atributnoj dopuni, u obliku konstrukcije »dvostrukoga akuzativa« (accusativus duplex). Budući da se takav particip sintaktički vezuje uz objekt, GRKOVIĆ-MEJDŽOR (2007: 233-236) smatra ga podvrstom determinativnoga participa (usp. ETEROVIĆ; VELA 2013: 9).
} 


\section{ZAKLJUČAK}

Kada je o participima riječ, hrvatskoglagoljski psaltiri (Lobkovicov, $\mathrm{Pa}$ riški i Fraščićev) koji u podlozi imaju jedinstven crkvenoslavenski prijevod s grčkoga kao i kanonski Sinajski psaltir, prenose grčki predložak odgovarajućim participnim konstrukcijama, u pridjevskim i glagolskim sintaktičkim uporabama.

Sklonost prenošenja grčkih pridjevskih beščlanskih participa određenim oblicima pokazuje se dvojakom: a) u pridjevskim determinativnim nizovima vjerojatno govori u prilog jačem isticanju atributnoga smisla i time njihovu dosljednijem i jasnijem razlikovanju od onih u kojima pretežu glagolska (predikatna) obilježja, osobito kada je riječ o nominativima; b) u slučajevima u kojima se pojavljuju na mjestu nedeterminativnih participa, bilo da je riječ o samo nekim (hrvatsko)crkvenoslavenskim spomenicima ili o svima, participi dobivaju na determinativnosti i konkretizaciji, a u nominativu i na većoj razlikovnosti u odnosu na pridjevske i glagolske participe u predikatnom položaju.

Grčki pridjevski participi rijetko se na crkvenoslavenski prenose odnosnom rečenicom, vjerojatno pod utjecajem latinske Vulgate. Relativna rijetkost priložnih participa u psaltiru, odnosno participa sporednih predikata uvjetovana je bezvremenskim karakterom mudrosne književnosti, kontekstualnim granicama psalamskih stihova i kolona, koje odlikuju jednostavnija rečenična obilježja, kao i razlikama u hebrejskoj i grčkoj sintaksi. U primjerima uzročnoga smisla dativ apsolutni dolazi kao prijevod konstrukcije áđó s infinitivom.

Iz navedenoga proizlazi da hrvatski crkvenoslavenski tekst u prijenosu participskih konstrukcija uglavnom pokazuje vjerno nasljedovanje grčkoga originala.

\section{IZVORI}

$\mathrm{PsFr}=$ Fraščićev psaltir, 1463.; HAMM, J. 1967. Psalterium Vindobonense: Der kommentierte glagolitische Psalter der Österreichischen Nationalbibliotek. (Österreichischen Akad. der Wissenschaften, Philosophischen-Historische Klasse, Schriften der Balkankommission, Linguistische Abteilung, 19). Wien: Hermann Böhlaus Nachf.

PsLob = Lobkovicov psaltir, 1359.; VAJS, J. 1916. Psalterium palaeoslovenicum croaticoglagoliticum: textum glagoliticum e Codicibus Pragensi et Parisiensi litteris cyrillicis exscriptum annotationibus variis lectionibus reliquorum codicum glossario instruxit Josef Vajs. Prag: Sumptibus Academiae Palaeoslavicae Veglensis. 
PsPar = Pariški psaltir, 1380.; VAJS 1916.

PsSin = Sinajski psaltir, 11. st.; SEVER'JANOV, S. 1922. Sinajskaja psaltyr'. Glagoličeskij pamjatnik XI veka. Prigotovil k pečati Sergej Sever'janov. Petrograd: Otdělenije Russkaho jazyka i slovesnosti Rossijskoj Akademii Nauk (IV); Pretisak: ${ }^{2}$ 1954. Graz: Akademische Druck (Editiones monumentorum slavicorum veteris dialecti, VII).

RAHLFS, A. 1931. Septuaginta Vetus Testamentum graecum. Psalmi cum Odis (Septuaginta Societatis Scientiarum Gottingensis, X). Göttingen: Vandenhoeck und Ruprecht.

Vg 1953 = Biblia sacra iuxta latinam vulgatam versionem ad codicum fidem iussu Pii pp. XII. Liber psalmorum ex recensione sancti Hieronymi. X Liber Psalmorum. Roma: Typis Polyglottis Vaticanis.

\section{LITERATURA}

AEJMELAEUS, A. 1982. Participium coniunctum as a Criterion of Translation Technique. Vetus Testamentum 32/4: 385-393.

BOYER, J. L. 1984. The Classification of Participles: A Statistical Study. Grace Theological Journal 5/2: 163-179.

BROWN, W. P. 2014. The Oxford Handbook of the Psalms. New York, NY: Oxford University Press.

BROWNING, R. 1983. Medieval and Modern Greek. Cambridge [Cambridgeshire]: Cambridge University Press.

CONYBEARE, F. C.; S. G. STOCK. (1905 [22004]). Grammar of Septuagint Greek: With Selected Readings, Vocabularies, and Updated Indexes. Peabody, MA: Hendrickson Publishers. [izvornik: 1905.]

DAMJANOVIĆ, S. 2003. Staroslavenski jezik. Zagreb: Hrvatska sveučilišna naklada.

DANA, H. E.; J. R. MANTEY. 1957. A Manual Grammar of the Greek New Testament. New York, N. Y.: The Macmillan Company. [izvornik: 1923.]

DUKAT, Z. 2003. Gramatika grčkoga jezika. Zagreb: Školska knjiga.

ETEROVIĆ, I.; J. VELA. 2013. Sintaktičke uloge participa u Misalu hruackome Šimuna Kožičića Benje. Slovo 63: 1-22.

GAUTHIER, R. 2009. Examining The Pluses In The Greek Psalter: A Study Of The Septuagint Translation Qua Communication. J. Cook (ed.). Septuagint and Reception. Leiden - Boston: Brill, 45-76.

GILLINGHAM, S. 2012. Psalms Through the Centuries, Volume One. Chichester: WileyBlackwell.

GRKOVIĆ-MEJDŽOR, J. 2001. Pitanja iz staroslovenske sintakse i leksike. Novi Sad: Filozofski fakultet u Novom Sadu [Lingvističke sveske, 1].

GRKOVIĆ-MEJDŽOR, J. 2007. Spisi iz istorijske lingvistike. Sremski Karlovci - Novi Sad: Izdavačka knjižarnica Zorana Stojanovića. 
HCJ 2014 = GADŽIJEVA, S.; A. KOVAČEVIĆ; M. MIHALJEVIĆ; S. POŽAR; J. REINHART; M. ŠIMIĆ; J. VINCE 2014. Hrvatski crkvenoslavenski jezik. A. Šikić i M. Mihaljević (ur.), priredio M. Mihaljević. Zagreb: Hrvatska sveučilišna naklada, Staroslavenski institut.

JOBES, K. H.; M. SILVA. 2000. Invitation to the Septuagint. Grand Rapids - Carlisle: Baker Academic and Paternoster Press.

JURČEVIĆ, I. 2004. Aktivni particip prezenta u hrvatskom crkvenoslavenskom jeziku. M. Mihaljević, M.-A. Dürrigl, F. Velčić (ur.). Glagoljica i hrvatski glagolizam. Zagreb - Krk: Staroslavenski institut i Krčka biskupija, 607-616.

KURZ, J. 1937-1938. K otázce členu v jazycích slovanských, se zvláštním zřetelem k staroslověnštině. Byzantinoslavica 7: 212-340.

KURZ, J. 1939-1946. K otázce členu v jazycích slovanských, se zvláštním zřetelem k staroslověnštině (Dokončení). Byzantinoslavica 8: 172-288.

MACROBERT, M. 1998. The Textual Tradition of the Church Slavonic Psalter up to the Fifteenth Century. J. Krašovec (ur.). Interpretation of the Bible - Interpretacija Svetega Pisma. Ljubljana - Sheffield: Slovenska akademija znanosti in umetnosti, Sheffield Academic Press, 921-942.

MIHALJEVIĆ, M. 2005. Sintaktička svojstva najstarijih hrvatskoglagoljskih tekstova. L. Taseva, R. Marti, M. Jovčeva (ur.). Meždunarodnata konferencija »Mnogokratnite prevodi v južnoslavjanskoto srednovekovie«. Sofija: Goreks Pres, 221-238.

MIHALJEVIĆ, M. 2009. Hrvatski crkvenoslavenski jezik. S. Damjanović (ur.). Povijest hrvatskoga jezika. 1. knjiga: Srednji vijek. Zagreb: Društvo za promicanje hrvatske kulture i znanosti CROATICA, 283-349.

MIHALJEVIĆ, M. 2011. Dopune percepcijskih glagola u hrvatskome crkvenoslavenskom jeziku. Suvremena lingvistika 72: 187-200.

MIHALJEVIĆ, M.; J. REINHART. 2005. The Croatian Redaction: Language and Literature. Incontri linguistici 28: 31-82.

MIHALJEVIĆ, M.; J. VINCE. 2012. Jezik hrvatskoglagoljskih Pazinskih fragmenata. Zagreb: Hrvatska sveučilišna naklada, Državni arhiv u Pazinu, Staroslavenski institut.

PASTRNEK, F. 1903. Die griechischen Artikelkonstruktionen in der altkirchenslavischen Psalter- und Evangelienübersetzung. Archiv für slavische Philologie 25: 366-391.

REINHART, J. 1993. Untersuchungen zur Syntax des Kroatisch-Kirchenslavischen. (Habilitationsschrift zur Erlangung der Lehrbefugnis.) Wien: Universität Wien.

ROBERTSON, A. T. 1915. A Grammar of the Greek New Testament in the Light of Historical Research. 4. izdanje. Nashville: Broadman Press.

RUBIO, G. 2009. Semitic influence in the history of Latin syntax. P. Baldi, P. Cuzzolin (eds.). New Perspectives on Historical Latin Syntax. Vol. 1: Syntax of the sentence. Berlin - New York: Mouton de Gruyter. 195-239.

RUNGE, S. E. 2016. The Contribution of Verb Forms, Connectives, and Dependency to Grounding Status in Nonnarrative Discourse. S. E. Runge, C. J. Fresch (eds.). The Greek Verb Revisited: A Fresh Approach for Biblical Exegesis. Bellingham, WA: Lexham Press, chapter 7 (e-book). 
RŮŽIČKA, R. 1963. Das syntaktische System der altslavischen Partizipien und sein Verhältnis zum Griechischen. Berlin: Akademie-Verlag.

SAILHAMER, J. H. 1991. The Translational Technique of the Greek Septuagint for the Hebrew Verbs and Participles in Psalms 3-41. New York - Frankfurt am Main - Paris: Peter Lang.

SOISALON-SOININEN, I. 1973. The Use of the Genitive Absolute in the Septuagint. (http://www.academia.edu/25828526/The_Use_of_the_Genitive_Absolute_in_the Septuagint_I._Soisalon-Soininen_10.07.2017.)

STANISLAV, J. 1933-1934. Datív absolutný v starej cirkevnej slovančine. Byzantinoslavica 5: 1-112.

STEK, J. H. 1974. The Stylistics of Hebrew Poetry. Calvin Theological Journal 9: 15-30.

STRAUB, B. 2010. The Case of Greek Participles: distinguishing between adjectival and adverbial Uses. (http://www.academia.edu/3488970/The_Case_of_Greek_Participles_ Distinguishing_between_Adjectival_and_Adverbial_Uses, 10.10. 2017.)

TURNER, N. 1963. A Grammar of New Testament Greek. J. H. Moulton. Vol. 3: Syntax, by N. Turner. Edinburgh: T. \& T. Clark.

VALJAVEC, M. 1889. O prijevodu psalama u nekijem rukopisima hrvatsko-srpsko i bugarsko-slovenskijem. Rad JAZU 98: 1-84.

VEČERKA, R. 1961. Syntax aktivních participií v staroslověnštině. Prag: Státní pedagogické nakladatelství.

VEČERKA, R. 1989. Altkirchenslavische (altbulgarische) Syntax I. Die lineare Satzorganisation. Freiburg i. Br.: U. W. Weiher.

VEČERKA, R. 1993. Altkirchenslavische (altbulgarische) Syntax II. Das innere Satzstruktur. Freiburg i. Br.: U. W. Weiher.

VEČERKA, R. 1996. Altkirchenslavische (altbulgarische) Syntax III. Die Satztypen: Der einfache Satz. Freiburg: Weiher Verlag.

VRTIČ, I. 2009. Sintaksa Kašićeva prijevoda Svetoga pisma (doktorska disertacija u rukopisu). Filozofski fakultet Sveučilišta u Zagrebu.

WALLACE, D. B. 1996. Greek Grammar beyond the Basics: An Exegetical Syntax of the New Testament. Grand Rapids, MI: Zondervan.

WALTKE, B. K.; M. P. O’CONNOR. 1990. An Introduction to Biblical Hebrew Syntax. Winona Lake: Eisenbrauns. 


\section{Summary}

\section{Lucija Turkalj}

\section{THE SYNTAX OF THE ACTIVE PARTICIPLES IN THE CROATIAN GLAGOLITIC PSALTER}

This paper analyses the active participial constructions in their adjectival (adjectival proper and substantival) and verbal (adverbial, periphrastic, independent participial predicate, complementary) uses in the Croatian Glagolitic Psalter corpus (Lobkovic, Paris and Fraščić psalter), by their comparison with the variant readings of the canonical Sinai Psalter and their source Greek text. An interesting appearance of variation of definite and indefinite inflectional forms, especially in the transfer of Greek anarthrous participles, points to the more difficult grammatical identification that can be caused by: common features of the participial types, timelessness as the characteristic of the non-literary genre, differences between two languages, indirect influence of the Hebrew syntax. Understanding of translating technique, occasional deviations as regards definiteness of inflectional forms in relation to the Greek source text, variations between Church Slavic manuscripts and the influence of the Latin Vulgate are taken into consideration.

Keywords: participle, syntax, Croatian Glagolitic Psalter, Croatian Church Slavonic language, Greek language

Ovaj je rad financirala Hrvatska zaklada za znanost projektom 2462. 